\title{
TEACHERS' ATTITUDES TOWARD THE INCLUSION OF STUDENTS WITH ATTENTION- DEFICIT/HYPERACTIVITY DISORDER (ADHD)
}

ATITUDINEA PROFESORILOR FAȚĂ DE INCLUZIUNEA ELEVILOR CU TULBURARE HIPERCHINETICĂ CU DEFICIT DE ATENTIIE (ADHD)

\section{Florentina LINCĂ}

\author{
Journal of Pedagogy, 2019 (2), 47 - 63 \\ https://doi.org/10.26755/RevPed/2019.2/47
}

The online version of this article can be found at: http://revped.ise.ro/category/2019-en/

\section{(c) (1)(2)(2)}

This work is licensed under the Creative Commons Attribution-NonCommercial-ShareAlike 4.0 International License. View, CA 94042, USA.

Published by:

\section{8.}

http://www.ise.ro/

Further information about Revista de Pedagogie - Journal of Pedagogy can be found at:

Editorial Policy: http://revped.ise.ro/editorial-policy/

Author Guidelines: http://revped.ise.ro/the-writer-guide-2/ 


\title{
TEACHERS'ATTITUDES TOWARD THE INCLUSION OF STUDENTS WITH ATTENTION- DEFICIT/HYPERACTIVITY DISORDER (ADHD)
}

\section{Florentina Ionela Lincă*}

\author{
University of Bucharest, \\ Faculty of Psychology and Educational Sciences, \\ Bucharest, Romania \\ linca.florentina@gmail.com
}

\begin{abstract}
In the last few decades, researchers in the field of education have paid particular attention to the inclusion of children with special educational needs (SEN) in mainstream schools. Children with Attention Deficit/Hyperactivity Disorder have been included among those with special support needs and special educational needs in the USA since 1990, when the Individuals with Disabilities Education Act (IDEA) was adopted. In Romania, although there is no specific legislation yet, in 1990 by Law 15, the Romanian Parliament ratified the Convention on the Rights of the Child, which laid the foundations for inclusion of children with special educational needs in mainstream school and society. This study aims to achieve two objectives. The first objective was to explore the relationship between the perception of primary school teachers about the severity of the symptoms of ADHD students, their attitude towards the integration of ADHD students in the school and their knowledge about ADHD. The second objective covered the aspects from the questionnaires applied and from the interview. The results show that the teachers' attitudes towards the integration of children with ADHD into mainstream schooling are often neutral, that primary school teachers have knowledge of the symptoms, etiology, and treatment of ADHD students, and that there is a mediating effect $(\mathrm{Z}=2.02, \mathrm{p}=0.044$, $\mathrm{p}<0.05$ ), which accounts for $36.6 \%$ of the total effect. It can be concluded that all the objectives have been achieved and the results can be used to carry out in-service training programs for primary school teachers.
\end{abstract}

* PhD. Candidate, University of Bucharest, Faculty of Psychology and Educational

Sciences, Department of Educational Sciences, Bucharest, Romania. 
Keywords: ADHD, integration, inclusive school, teachers' attitudes, teachers' understanding.

\section{Rezumat}

In ultimele decenii, cercetătorii din domeniul ştiin elor educa iei au acordat o aten ie deosebită incluziunii copiilor cu cerin e educa ionale speciale (CES) în şcolile de masă. Copilul cu tulburarea ADHD a fost inclus în rândul celor cu CES în SUA încă din anul 1990 când s-a adoptat Legea privind educa ia persoanelor cu dizabilită $i$ (Individuals with Disabilities Education Act/IDEA), iar în România, deşi nu există o legisla ie specifică, încă din 1990 prin Legea 15, Parlamentul României a ratificat Conven ia cu privire la drepturile copilului prin care se puneau bazele incluziunii copilului cu CES în şcoala de masă şi în societate. Acest studiu urmăreşte atingerea a două obiective. Primul obiectiv a pus accent pe examinarea rela iei dintre percep ia cadrelor didactice din învă ământul primar de masă asupra severită ii simptomatologiei elevilor cu ADHD, atitudinea acestora fa $\breve{a}$ de integrarea elevilor cu ADHD în şcoală şi cunoştin ele lor despre ADHD. Al doilea obiectiv a vizat aspectele din chestionarele aplicate şi din interviu. Rezultatele arată că atitudinea cadrelor didactice fa $\breve{a}$ de integrarea copiilor cu ADHD în şcoala de masă este, de cele mai multe ori, neutră, că profesorii din învă ământul de masă au cunoştin e despre simptomatologia, etiologia şi tratamentul în cazul elevilor cu $A D H D$ şi că există un efect de mediere $(Z=2,02, p=0,044, p<0,05)$, iar acesta contabilizează $36,6 \%$ din efectul total. Se poate concluziona că toate obiectivele au fost atinse, iar rezultatele pot fi utilizate pentru realizarea unor programe de formare continuă pentru cadrele didactice din învă ământul primar de masă.

Cuvinte-cheie: $A D H D$, atitudinea cadrelor didactice, cunoştin ele cadrelor didactice, integrare, şcoală incluzivă.

\section{Introduction}

In recent decades, researchers in the domain of education sciences have paid particular attention to the inclusion of children with special educational needs (SEN) in mainstream schools. A decisive issue is the extent to which they are helped to adapt, to achieve the educational goals that are set and to participate in school life (Pachigar et al., 2011). In other words, the discussion turns around how students can be provided with an optimal education in accordance with their abilities and needs, whereas there has long been a 
misconception that the inclusion of people with special needs in mainstream schooling is just placing them in classrooms, without including them. (Ince, 2012; Winter, 2006).

Not all inclusive schools have always performed well, but it has been proven that the success of inclusion depends on many factors, such as: changes in educational policies, legislation and administrative structures, availability of adapted materials and resources (adapted curriculum), the skills of the teacher in classroom management, his/her willingness to integrate such a child into the classroom and the teachers' perception on their self-efficacy (Bradshaw \& Mundia, 2006; Oswald \& Swart, 2011).

Children with attention deficit/hyperactivity disorder have been included among those with support needs and special educational needs in the US since 1990 when the Individuals with Disabilities Education Act (IDEA) was adopted (Bailey, 2007). Children diagnosed with ADHD are eligible for special educational services if they also have learning difficulties, thus being included in an individualized educational program (IEP).

In Romania there is no specific law for Attention-Deficit/Hyperactivity Disorder (ADHD), but in 1990 by Law no. 15, the Romanian Parliament ratified the Convention on the rights of the child which laid the basis for the inclusion of the child with SEN in the mainstream school and in society. In 1995 , by Law no. 84, the education for all students with/without SEN is ensured, and starting with 2000 the students with SEN benefit from a psychopedagogical teacher and a support teacher. Since 2001, efforts have been made to improve inclusive mainstream education, but there is a need to change educational practices by investing in the initial training of teachers (Vrăsmaş, 2004).

This study aimed to investigate whether the perception of teachers in primary school on the severity of ADHD symptomatology could explain the causal relationship between the attitude of teachers towards the integration of ADHD students into mainstream school and their knowledge about ADHD. On the other hand, this study aims to analyze the answers of the teachers from the mainstream schools both to the items of the questionnaires applied, as well as to the interview questions regarding the studied topic. 
Explicitly, this study has the following objectives:

O1. Analysis of the response of the teachers in the mainstream school to the items of the questionnaires that measure, on the one hand, their attitude regarding the integration of the students with ADHD in their school and the general knowledge about ADHD, and, on the other hand, the way they see the severity of symptoms of ADHD students.

O2.Exploring the relationship between the perception of primary school teachers about the severity of the symptoms of ADHD students, their attitude towards the integration of ADHD students in the school and their knowledge about ADHD.

In order to achieve the objectives, the research hypothesis was constructed and verified:

I1. It was assumed that the perception of the teachers in the mainstream school about the severity of the symptoms of the students with ADHD mediates the relationship between their attitude towards the integration of the students with ADHD in the mainstream school and their knowledge about ADHD.

\section{Methods}

In this study, the questionnaire-based survey method and the interview method were used, because we wanted to get information as close to reality as possible.

To measure the research variables, 3 questionnaires were created starting from the analysis and the translation of the items of the following scales: The Concerns about Inclusive Education scale (CIE) realized by Sharma and Desai (2002); The Knowledge of Attention Deficit Disorders Scale (KADDS) by Sciutto, Nolfi and Bluhm (2000), Teacher Knowledge of Stimulant Medication and ADHD by Snider, Busch and Arrowood (2003) and The Knowledge of Attention Deficit/Hyperactivity Disorders Scale KADHD performed by Jerome et al. (1994), with dichotomous answer ( $T=$ true and $\mathrm{F}=$ false), where participants receive 1 point for each correct answer; The ADHD Child Evaluation (ACE) by Young (2015) with dichotomous answer Yes/No, where participants receive 1 point for each answer of Yes. 
Then, we modified some of their items in relation to ADHD criteria in DSM 5 and added other items that take into account the etiology of ADHD, as well as pharmacological, psychotherapeutic and psycho-pedagogical interventions for students with such a disorder.

The calculation of the Cronbach Alpha correlation coefficients indicates a good internal consistency, accepted in the research $(0,7-0,8)$ (Table no. 1).

Table no. 1. Cronbach's Alpha for all scales

\begin{tabular}{lc}
\hline $\begin{array}{l}\text { Attitude towards integration Scale } \\
\text { Cronbach's Alpha }\end{array}$ & Number of Items \\
0.804 & 12 \\
The teacher's perception of the severity of the student's symptoms with ADHD Scale \\
Cronbach's Alpha & Number of Items \\
0.733 & 23 \\
ADHD Knowledge Scale & Number of Items \\
Cronbach's Alpha & 18 \\
0.701 &
\end{tabular}

The questionnaires were translated by the author of this study and sent for revision to three other specialists: a clinical psychologist, a psychopedagogical psychologist and an English teacher. According to the observations of the three specialists, modifications were made in order to adapt the instruments to the specific traits of the Romanian language. The questionnaires were disseminated in printed version. Firstly, a number of 7 school principals from Teleorman County were contacted to request their agreement to disseminate the questionnaires among teachers working with students diagnosed with ADHD (grades 1-4). After obtaining their consent, both informed consent forms and teacher questionnaires were given. In order to obtain the results of the questionnaires, the teachers participating in the study were clearly explained what they should do. Also, the clinical interview was carried out with the help of the teachers in the classroom, who knew very well the behavioral manifestations of each child. Participation was voluntary.

Out of the 80 questionnaires disseminated, only 60 were completed correctly 
and sent back to the researcher, these representing the group of the present research. The data obtained were centralized in Excel documents, then transferred to the statistical analysis program SPSS 22 and JAMOVI. In order to ensure confidentiality, all the documents were analyzed, and the personal data (such as: the name of the teacher or the student, the telephone number of the teacher, the address of the child/teacher) were not collected. Next, the processing and interpretation of the obtained data were performed.

\section{Results and discussion}

Further, teachers' responses to the interview were analyzed based on content analysis (O1).

All teachers said that the number of students in the class was not reduced, and more than 4 of the teachers from 4 different schools reported a number of 5 students diagnosed with ADHD in a class on a total of 34 students. One teacher reported that in his class with a total of 35 students, 5 of them have ADHD, diagnosed by a psychiatrist, and only one has special educational needs without a support teacher.

There are also situations in which the number of students in the class is relatively small (17 students), from which 5 are diagnosed with ADHD, without special educational needs. This fact was reported by 4 teachers from a single school.

Only 3 of the teachers participating in the study, employees of the same educational institution, reported that in their classes they have a single child with ADHD without special educational requirements, on a total number of 25 students, and only one teacher reported that in his class he has a student diagnosed with ADHD from a total of 21 students.

On the other hand, when exploring the response to the question: What methods do you apply for maintaining the discipline in the classroom?, based on the analysis of the content of the answers, the answers can be grouped into 3 categories: pedagogical and psycho-pedagogical methods, psychotherapeutic methods and techniques and the values of the teachers (Figure no. 1). 


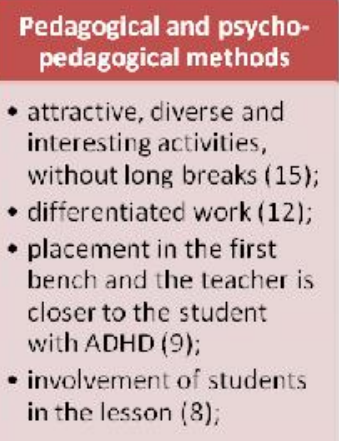

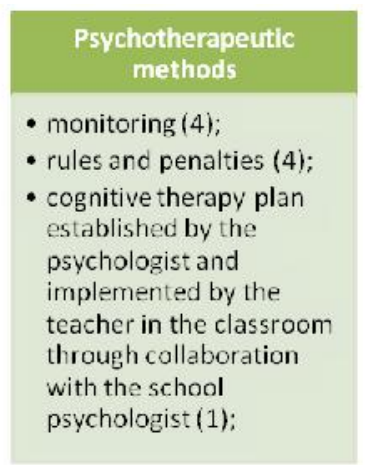

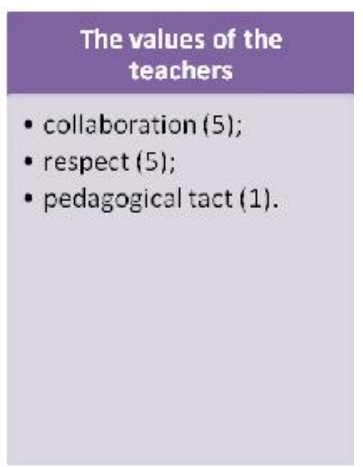

Figure no. 1. Graphic representation of the teachers' answers

In conclusion, the interviewed teachers use a wide range of methods to maintain an optimal learning environment for all students with/without SEN. All of these, according to Döpfner, Schürmann and Frölich (2006), determine the life skills of ADHD students.

Which are the main skills of the teacher needed to work effectively with students with ADHD? is another question from the interview to which the answers could be grouped into 3 categories: the values of the teachers, the behaviors of the teachers in the classroom and their knowledge about ADHD (Figure no. 2).

In addition, the teachers have said: knowledge from several domains (pedagogical, psychological, psycho-pedagogical) helps us in the classroom management. Patience, understanding, psycho-pedagogical understanding and preparation support the teacher to work effectively with students with ADHD. Human values, as seen from the frequencies, are important in this context.

In the schools where the interview was conducted, there is no specialist other than the school psychologist, and the funds to pay a support teacher are insufficient.

Regarding the participation in courses where it is explained to the teachers how to work with a child with ADHD, all the educators said that they did 


\section{The values of the teachers}

- patience (44);

- understanding (17);

- love for children (8);

- gentleness (8);

- empathy (5);

- seriousness (3);

\section{The behaviors of the teachers in the classroom}

- psycho-pedagogical training (13);

- perseverance (12);

- distributive attention (8);

- experience (3);

- involvement (2);

- discouraging negative behaviors (2);

- close supervision (2);

\section{Knowledge}

- knowledge of specific working methods (10);

- knowledge of the characteristics of the child with ADHD (2);

- knowledge of behavioral therapies (1).

Figure no. 2. The main skills of the teacher required to work effectively with students diagnosed with ADHD

not know that the Ministry of Education had organized further training courses in this domain, but most of the information on this subject is from online sources or from the school psychologist or from the biology teacher. Another part of the interview consisted of teachers describing the relationships that students with ADHD have with peers. 15 of the teachers said that the student to whom they reported is friendly with the other colleagues, 14 teachers said that the student to whom they reported has bad relationships with the other students and that he is often verbally and physically aggressive, and 31 teachers reported that students with ADHD have good relationships only with those with discipline problems, aggressive and hostile.

These results are also supported by the literature. Barkley (2012) argued that these students fail to learn their norms, the social rules specific to their chronological age, due to symptomatology, especially hyperactivity. 
Among the disorders most commonly associated with ADHD in pupils reported by teachers and primary school teachers are:

1. Cognitive Deficits (21 teachers reported this aspect).

2. Oppositional Deviant Disorder (18 teachers reported this aspect).

3. Communication and Language Disorders (17 teachers reported this aspect).

4. Behavioral Disorders, Anxious Disorders (13 teachers reported this aspect).

According to those reported by teachers, 5 of the students had more than 5 associated disorders, 14 of the students had 3 associated disorders, 8 of the students had 4 associated disorders.

Another aspect highlighted in this part of the interview is the one related to the existence of early risk factors. Thus, the most frequent are:

1. maternal smoking during pregnancy (20 of the students);

2. early traumas (e.g., physical, sexual, emotional abuse) (found in 13 of the students);

3. preterm birth (is found in 11 of the students);

4. low birth weight (is found in 10 of the students).

At the same time, analyzing the answers to the Questionnaire that measures the Attitude of the Teachers regarding the Integration of the Small School with ADHD in the Mainstream Education, it was observed that the students with ADHD are more easily accepted by the other students, as compared to the parents of the other students, proof being higher scores on the first item (55\% of the students accept the student with ADHD in a suitable measure) compared to the second item (48.3\% of the parents accept to a small extent that in the class in which their child is enrolled and a student with ADHD). Regarding the teacher's workload since integrating a student with ADHD into his/her class, this has not changed in most cases. 15 (25\%) of the teachers reported that they have been working more than ever since they have ADHD students in their class, some having 5 ADHD students out of a total of 35 . On the other hand, giving equal attention to all students is considered a difficult activity by $21 \%$ of the teachers, while half of the respondents claim that it is not an extraordinary effort. One of the mechanisms that help them is patience, as reported in the interview. 
Overall, integrating students with ADHD into mainstream school is considered a desirable educational practice by half of the respondents, while only 4 of the teachers $(6.7 \%)$ consider it desirable to a very large extent.

At the same time, the questions regarding the fundamental principles of integration (items 7-12) highlighted the following aspects: half of the respondents argue that it is important to discuss the person first and only then the incapacity he/she has, $45 \%$ of the respondents say that any person possesses unique skills and talents, $46.7 \%$ of the respondents consider that a person with special educational needs/ADHD can participate in social/ school life, $33.3 \%$ of the teachers have a neutral attitude when it comes to educational and social benefits as a result of the integration of students with ADHD in the mainstream education classes, and 23 (38.3\%) of the teachers consider that the success of the integration of the student with special educational needs/ADHD depends on his/her own attitude.

In conclusion, the attitude of the teachers towards the integration of children with ADHD in primary school is mostly neutral (33.3\%), but there are quite a few cases that see the child with ADHD as one who can integrate and who can participate actively in school life (46.7\%). Patience, understanding, dedication and empathy are some of the most important attributes of teachers in working with these students. The teachers claim that knowledge from several domains (pedagogical, psychological, psycho-pedagogical) is needed for a good classroom management.

Teachers from the mainstream school have knowledge about both symptomatology, etiology, and treatment for students with ADHD.

Six of the teachers answered correctly to all the test items, 6 at $94.74 \%$ of the test items (17 items resolved correctly from the total of 18 items), 7 of the teachers answered correctly at $90 \%$ of the test items (16 items resolved correctly), and 4 of the teachers answered correctly at $50 \%$ of the test items, the lowest score.

There were, however, cases in which the proportion of wrong answers was higher than that of correct ones. An example of an item is: If a child is playing on the PlayStation 4 Pro for hours, he or she probably does not 
have ADHD, to which only $43.3 \%$ of the teachers answered correctly. Other registered gaps are present in the domain of causes and treatment of ADHD in childhood.

In the items that considered the causes of ADHD, 31.7\% (19) of the participants said that sugar or food additives are the basis of the disorder, $28.3 \%$ (17) considered that ADHD is due to inappropriate parental practices (pampering) and $31.7 \%$ (19) said that ADHD is the result of a chaotic family environment.

One possible explanation for this result would be that the media promotes the negative effects of excessive sugar consumption, but also the myth that the child with ADHD is the result of a bad education. In the United States, there was an overdiagnosis of the students in the primary cycle with ADHD, proof being the high number of drugs sold to treat it (US Department of Education, 2006). Thus, there was a confusion between Attention Deficit/ Hyperactivity Disorder and Behavioral Disorders, but also inappropriate intervention. The distinction between these disorders has been made clear with the popularization of the use of DSM in diagnosing mental health disorders in childhood.

Regarding the treatment of Attention Deficit/Hyperactivity Disorder, there are still gaps in the knowledge of the teachers. 35\% (21) of them mistakenly believe that tics of students with ADHD are not a side effect of stimulant drug use, and $11.7 \%$ ( 7 teachers) believe that ADHD can only be treated with pharmacological therapy.

Other items with a large number of incorrect answers were those referring to the test results of the student with ADHD (20\% of the study participants answered incorrectly) and to the fact that they will behave normally at maturity $(23,3 \%$ of the study participants answered incorrectly).

The teachers explain that although the students with ADHD are intelligent and creative, due to their hyperactivity and attention deficit, they cannot stay focused for a long time on a test and hence the poor learning outcomes.

The seriousness, the establishment of clear educational objectives, the 
observance of strict rules and the persistence of the teachers, as they argue in the interview regarding the integration of the students with ADHD in the primary school, determine the disappearance of the negative behaviors in the classroom. Other teachers consider that changing the behavior of the student with ADHD in the school environment is determined by the kindness, gentleness and understanding of the adult. Thus, everyone concludes that a child with ADHD will behave normally in adolescence and then in adulthood if he or she intervenes early in school.

Unfortunately, ADHD does not heal, this disorder of the student's mental health having a genetic cause (American Psychiatric Association, 2013). What can be done, however, is an improvement in the frequency and intensity of the symptomatology, which has, of course, effects on both the learning outcomes and the student's social functioning.

Regarding the questionnaire that measures the symptoms of ADHD in small students, teachers argue that most students have a mixed type, which is illustrated by the number of cases reported for each symptom. Thus, we can say that the first objective was achieved.

Based on the information obtained from both the interview and the questionnaires applied to teachers in primary school, we can carry out training programs for teachers, but also for students with ADHD through the involvement of teachers. Online sources, TV shows are not, for the most part, based on scientifically validated information, and thus myths about this disorder appear. The myths, besides the fact that they influence the attitude of the adult towards the child with ADHD, also determine the application of interventions in discordance with the problems of the child. All this can be avoided by correct and complete information from official sources and/or scientifically validated ones.

Teacher training programs, on the other hand, need to draw their attention to the importance of raising awareness that ADHD is a real health issue that causes many problems in all areas of a child's life and that by early intervention we can teach talented and intelligent children how to avoid obstacles or overcome a large part of them. 
Medication is useful, but it is not the only form of beneficial therapy for students with ADHD. Non-pharmacological therapies help the child to solve only some of the problems. For example, interventions based on cognitivebehavioral therapy help the child to replace dysfunctional behavior with a functional, adaptable one (Döpfner, Schürmann \& Frölich, 2006; Petermann \& Peterman, 2006).

Another important aspect to be discussed in the training programs is the realization by the teachers of the functional analysis of the behavior of the child with ADHD. Interventions in the school environment based on a correct functional assessment of the behavioral patterns of the student with ADHD are effective in reducing the child's symptoms, but also in improving the poor learning outcomes. In other words, through these interventions the child with ADHD develops in addition to the school skills, the ability to adapt to the environment.

Interventions in the school environment lead to the formation and generalization of socially desirable behaviors for children with ADHD.

To reach the second objective, we tested the hypothesis that the perception of the teachers in the mainstream school about the severity of the symptoms of the students with ADHD mediates the relation between the attitude of the teachers towards the integration of the students with ADHD in the mainstream school and their knowledge about ADHD.

As can be seen from the table below, all variables have a normal distribution of values, and the results of the Kolmogorov-Smirnov Test are as follows: 
Table no. 2. Normality test of distribution

\begin{tabular}{lllll}
\hline & & Attitude & Knowledge & Symptoms \\
\hline N & & 60 & 60 & 60 \\
& $\begin{array}{l}\text { Mean } \\
\text { Std. }\end{array}$ & 38.00 & 13.85 & 17.72 \\
Most Extreme & Deviation & 5.938 & 2.730 & 2.775 \\
Absolute & 0.111 & 0,113 & 0.111 \\
Differences & Positive & 0.111 & 0.087 & 0.076 \\
Test Statistic & Negative & -0.111 & -0.113 & -0.111 \\
Asymp. Sig. (2-tailed) & & 0.111 & 0.113 & 0.111 \\
\hline
\end{tabular}

a. Test distribution is Normal.

b. Calculated from data.

c. Lilliefors Significance Correction.

Next, we applied the mediation procedure through the MEDMOD module from the JAMOVI statistical analysis program.

Table no. 3 shows that the indirect effect differs significantly from zero, which illustrates that there is indeed a mediation effect $(\mathrm{Z}=2.02, \mathrm{p}=0.044$, $\mathrm{p}<0.05)$, and this accounts for $36,6 \%$ of the total effect.

Table no. 3. Mediation Estimates

\begin{tabular}{lllllll}
\hline Effect & Lable & Estimate & SE & $\mathrm{Z}$ & $\mathrm{p}$ & \% Mediation \\
\cline { 1 - 3 } Indirect & $\mathrm{a} \times \mathrm{b}$ & 0.286 & 0.142 & 2.02 & 0.044 & 36.6 \\
Direct & $\mathrm{c}$ & 0.496 & 0.241 & 2.06 & 0.039 & 63.4 \\
Total & $\mathrm{c}+\mathrm{a} \times \mathrm{b}$ & 0.782 & 0.262 & 2.99 & 0.003 & 100.0 \\
\hline
\end{tabular}


For the exact nature of the mediation effect we will analyze the path estimates (Table no. 4); the level of knowledge about ADHD influences the teachers' perception on the severity of the symptoms of the students with ADHD $(\mathrm{Z}=2.30, \mathrm{p}=0.021)$, which in turn has an effect on the attitude towards integration $(Z=4.17, \mathrm{p}<0.001)$.

It can therefore be concluded that the research hypothesis is supported by statistical data.

Table no. 4. Path Estimates

\begin{tabular}{ccccccl}
\hline & & Lable & Estimate & $\mathrm{SE}$ & $\mathrm{Z}$ & $\mathrm{p}$ \\
$\mathrm{y}$ & $\rightarrow$ & $\mathrm{a}$ & 0.290 & 0.126 & 2.30 & 0.021 \\
$\mathrm{~S}$ & $\rightarrow$ & $\mathrm{b}$ & 0.988 & 0.237 & 4.17 & $<.001$ \\
$\mathrm{C}$ & $\rightarrow$ & $\mathrm{c}$ & 0.496 & 0.241 & 2.06 & 0.039 \\
\hline
\end{tabular}

These results are similar to those in the literature. Teachers who have a high level of knowledge about Attention Deficit/Hyperactivity Disorder tend to have a positive attitude towards ADHD students, but have a high degree of distrust in their own strengths regarding the adoption of the most appropriate classroom management strategies in which a student with ADHD is integrated. The mechanisms that could explain this phenomenon are not yet known. At the same time, teachers with medium and high knowledge about ADHD are much more willing to accept the help of other specialists for managing stressful situations in the classroom, as opposed to those with a low level of knowledge (Ohan, Cormier, Hepp, Visser \& Strain, 2008).

It can be concluded that all the objectives have been achieved.

Regarding the limits of this study, it can be said that the number of participants was small, and the selection was of convenience. The instruments used, although translated according to the rules established in the domain, do not have sufficient references. 
One of the future directions of this study would be to investigate other variables that might explain the relationship between the attitude of the teachers regarding the integration of the students with ADHD in the mainstream school and their knowledge about this disorder.

\section{References}

- American Psychiatric Association. (2013). Diagnostic and statistical manual of mental disorders (5th ed.). Washington, DC: American Psychiatric Association.

- Barkley, R. A. (2012). Attention defficit hyperactivity disorder: A handbook for diagnosis and treatment (3rd ed.). New York, NY: Guilford Press.

- Bailey, E. (2007). How IDEA Applies to Children with ADHD. Retrieved from https://www.healthcentral.com/article/how-idea-applies-to-children-with-adhd.

- Bradshaw, L., \& Mundia, L. (2006). Attitudes to and concerns about inclusive education: Bruneian in-service and pre-service teachers. International Journal of Special Education, 21(1), 35-41.

- Döpfner, M., Schürmann, S., \& Frölich, J. (2006). Program psihoterapeutic pentru copii cu tulburare hiperchinetică şi comportamente de tip opozi ional (THOP). Cluj-Napoca: Editura RTS.

- Ince, S. (2012). Preschool teacher candidates' attitudes and concerns about inclusive education taking into consideration whether they took special courses or not at university. International Journal of Early Childhood Education and Research, 1(3), 1-19.

- Jerome, L., Gordon, M., \& Hustler, P. (1994). A comparison of American and Canadian teachers' knowledge and attitudes toward Attention Deficit Hyperactivity Disorder (ADHD). Canadian Journal of Psychiatry, 39(9), 563567. https://doi.org/10.1177/070674379403900909

- Ohan, J. L., Cormier, N., Hepp, S. L., Visser, T. A. W., \& Strain, M. C. (2008). Does knowledge about attention-deficit/hyperactivity disorder impact teachers' reported behaviors and perceptions? School Psychology Quarterly, 23(3), 436449. https://doi.org/10.1037/1045-3830.23.3.43

- Oswald, M., \& Swart, E. (2011). Addressing South African pre-service teachers' sentiments, attitudes and concerns regarding inclusive education. International Journal of Disability Development and Education, 58(4), 389-403. https:// doi.org/10.1080/1034912X.2011.626665

- Pachigar, V., Stansûeld, J., \& Goldbart, J. (2011). Beliefs and attitudes of primary school teachers in Mumbai, India towards children who stutter. International Journal of Disability Development and Education, 58(3), 287302. https://doi.org/10.1080/1034912X.2011.598664 
- Sciutto, M., Terjesen, M., \& Bender, A. (2000). Teachers' knowledge and misperceptions of Attention-Deficit/Hyperactivity Disorder. Psychology in the Schools, 37(2), 115-122.

- Sharma, U., \& Desai, I. (2002). Measuring concerns about integrated education in India. Asia and Pacific Journal on Disability, 5(1), 2-14.

- Snider, V. E., Busch, T., \& Arrowood, L. (2003). Teacher Knowledge of Stimulant Medication and ADHD. Remedial and Special Education, 24(1), 4656. https://doi.org/10.1177/074193250302400105

- U.S. Department of Education. (2006). Teaching children with attention deficit and hyperactivity disorder: Instructional strategies and practices. Retrieved from www.ed.gov/about/offices/list/osers/osep

- Vrăsmaş, T. (2004). Şcoala şi educa ia pentru to i. Bucureşti: Editura Miniped.

- Winter, E. C. (2006). Preparing new teachers for inclusive schools and classrooms. Support for Learning, 21(2), 85-91. https://doi.org/10.1111/j.14679604.2006.00409.x

- Young, S. (2015). The ADHD Child Evaluation (ACE). Retrieved from http:// www.divacenter.eu/Content/Downloads/ACE.pdf

The online version of this article can be found at: http://revped.ise.ro/category/2019-en/

\section{$(\mathrm{Cc})$ EY-NC-sA}

This work is licensed under the Creative Commons Attribution-NonCommercial-ShareAlike 4.0 International License.

To view a copy of this license, visit http://creativecommons.org/licenses/by-nc-sa/4.0/ or send a letter to Creative Commons, PO Box 1866, Mountain View, CA 94042, USA.
Versiunea online a acestui articol poate fi găsită la: http://revped.ise.ro/category/2019-ro/

\section{(cc) BY-NC- $\mathrm{BA}$}

Această lucrare este licen iată sub Creative Commons Attribution-NonCommercial-ShareAlike 4.0 International License.

Pentru a vedea o copie a acestei licen e, vizita $i$ http://creativecommons.org/licenses/by-nc-sa/4.0/ sau trimite i o scrisoare către Creative Commons, PO Box 1866, Mountain View, CA 94042, SUA. 